\title{
ethic \\ A FILOSOFIA TRANSUMANISTA SUBJACENTE AOS APRIMORAMENTOS NEUROCOGNITIVOS E O RISCO DE FRAGMENTAÇÃO DO BEM COMUM
}

\author{
THE TRANSHUMANIST PHILOSOPHY UNDERLYING \\ NEUROCOGNITIVE ENHANCEMENTS AND THE RISK OF \\ COMMON GOOD FRAGMENTATION
}

\author{
LUCAS VIANNA ${ }^{1}$ \\ (UNIJUÍ/Brasil) \\ LUIZ ADRIANO GONÇALVES BORGES ${ }^{2}$ \\ (UTFPR/Brasil)
}

\begin{abstract}
RESUMO
Nesse artigo, abordamos a filosofia transumanista subjacente aos aprimoramentos neurocognitivos. Esboçaremos uma crítica ético-social ao movimento, a partir da revisão bibliográfica de obras de C. S. Lewis, Michael Polanyi, Jürgen Habermas, Francis Fukuyama, Leon Kaas, Michael Sandel, John Finnis e Jacques Maritain. Também abordamos a questão do bem comum em face do transumano e as consequências que poderiam advir de não se pensar eticamente nas implicações do aprimoramento cognitivo. Concluiu-se que o "bem comum" previsto na filosofia transumanista carece de um preenchimento adequado do termo. $\mathrm{O}$ bem comum aristotélico é, antes de tudo, uma coordenação virtuosa dos bens particulares. Considerando, todavia, que tais bens estão ligados à natureza humana, que pode ser substancialmente alterada pelas transformações transumanistas, há dois riscos que se apresentam: ou que se busque modificar o estatuto humano de todos em uma pretensão hegemônica violadora da liberdade individual; ou, numa perspectiva liberal, que a transformação apenas daqueles que assim optarem francione a própria ontologia humana. Assim, poderia se tornar impossível falar de bem comum, visto que este deriva-se da coordenação de bens particulares que, em última instância, dependem do compartilhamento de um estatuto ontológico comum.
\end{abstract}

Palavras-chave: Transumanismo; Bem comum; Neoaristotelismo; Neuroética.

\begin{abstract}
In this article, we address the transhumanist philosophy underlying neurocognitive enhancements. We will outline an ethical-social critique of the movement, based on a bibliographic review of works by C. S. Lewis, Michael Polanyi, Jürgen Habermas, Francis Fukuyama, Leon Kaas, Michael Sandel, John Finnis and Jacques Maritain. We also address the issue of the common good in the face of the transhuman and the consequences that could arise from not thinking ethically about the implications of cognitive enhancement. We concluded that the "common
\end{abstract}


good" foreseen in the transhumanist philosophy lacks an adequate completion of the term. The Aristotelian common good is, above all, a virtuous coordination of private goods. Considering, however, that these goods are linked to human nature, which can be substantially altered by transhumanist transformations, there are two risks that present themselves: or that one seeks to modify the human status of all in a hegemonic claim that violates individual freedom; or, in a liberal perspective, that the transformation of only those who so choose will jeopardize human ontology itself. Thus, it could become impossible to speak of the common good, since it derives from the coordination of private goods that, ultimately, depend on the sharing of a common ontological status.

Keywords: Transhumanism; Common good; Neoaristotelianism; Neuroethics.

\section{Introdução}

Aprimoramento neurocognitivo não é novidade na história humana. As estratégias mais antigas e conhecidas são a glicose e a cafeína. Atualmente, porém, mesmo com as "drogas da inteligência", tais como a ritalina, temos a possibilidade de fazer uma bioengenharia do cérebro e dar um salto de inteligência inimaginável com medicamentos conhecidos. Em muitas culturas a aquisição de sabedoria é algo que se busca junto aos deuses (ou a um Deus nas culturas monoteístas). O deus hindu Ganesha, o deus nórdico Odin, os deuses gregos Athena e Prometeu representavam a sabedoria. Yahweh dos judeus é considerado "fonte de toda a sabedoria" e a busca autônoma por parte dos primeiros humanos por conhecimento os levou a serem expulsos do paraíso. O que parece estar sempre presente nas mitologias e histórias é o cuidado que se deve ter com a busca por conhecimento a qualquer preço. Ter prudência e pensar no bem comum são bons elementos para balizar essa busca, e é isso que argumentaremos ao longo do texto.

O sonho transumanista, de ontem e de hoje, enfoca três grandes esforços principais: aperfeiçoamento corporal, imortalidade e ampliação de inteligência. Neste artigo vamos nos deter sobre este último anseio, que hoje em dia se apresenta através do aperfeiçoamento neurocognitivo. Buscamos apontar em que aspectos o transumanismo falha em pensar no bem comum quando defende o aprimoramento, ainda que em seus discursos argumentem que estão pensando também nestas bases.

Tomemos um exemplo literário para darmos início à nossa argumentação: a história de Charlie Gordon no livro de ficção científica "Flores para Algernon" de 1966. Escrito por Daniel Keyes, esta obra surgiu como conto sete anos antes de sua versão final como livro e conta o antes e depois de uma operação para aumento de inteligência. A história é narrada do ponto de vista do próprio paciente, Charlie, que antes um jovem 
com QI baixo, tem sua inteligência paulatinamente ampliada após uma operação. Acompanhamos sua evolução, com um raciocínio cada vez mais refinado, o que impacta até na estrutura de sua narrativa, mas também somos confrontados pelos problemas emocionais inesperados. Emocionalmente ele é uma criança que não sabe lidar com as complexidades de um grande intelecto. E mais: os cientistas não previram esses e outros efeitos que advieram com a operação. $O$ autor parece querer questionar o status da ciência e a maneira como tem se pensado sobre o papel da inteligência em nossas sociedades, com uma mistura de incompreensão e sobrevalorização, além de imprudência no que se refere às potencialidades da ciência e da tecnologia. Assim, apesar de não ser novidade na história da humanidade, a busca por suplantar as limitações humanas começou a ter uma grande mudança no início do século XX. A filosofia e os avanços científicos e tecnológicos andavam próximos, mas eticamente ocorria um descompasso.

Nesse artigo, olhamos para a filosofia do movimento transumanista, buscando suas origens no início do século $X X$ e também olhando para o movimento atual, especialmente para os proponentes que pensaram em questões de bem comum. Esboçamos uma crítica ético-social ao movimento, levando em consideração autores como C. S. Lewis, Michael Polanyi, Jürgen Habermas, Francis Fukuyama, Leon Kaas, Michael Sandel, John Finnis e Jacques Maritain. Também abordamos a questão do bem comum em face do transumano e as consequências que poderiam advir de não se pensar eticamente nas implicações do aprimoramento cognitivo. Nosso intuito é contribuir para as discussões filosóficas para uma techné que sirva melhor ao bem comum.

\section{Transumanismo e aprimoramento neurocognitivo}

O transumanismo contemporâneo foi um movimento iniciado na década de 1920 pelos cientistas ingleses J. S. B. Haldane, Julian Huxley e John Desmond Bernal que, apoiados pelas recentes descobertas em biologia, anteviram e lançaram um programa para aperfeiçoamento humano. Para estes autores havia uma necessidade premente para se conduzir o melhoramento humano através da ciência e da tecnologia, e sua busca era conquistar, paulatinamente, o prolongamento da vida, curar o corpo humano de doenças, vencer a morte atingindo assim a imortalidade. Para isso, alguns passos precisavam ser dados, como retirar o homem da carcaça física e limitada que seria o corpo.

Haldane (1892-1964) foi geneticista e teórico matemático da evolução biológica e em 1923 publicou um panfleto bastante influente para 
o movimento transumanista (CLARK, 1968) chamado "Daedalus or the Science of the future" [Dédalo ou a ciência do futuro] (HALDANE, 1923). Neste panfleto ele tratava do papel das tecnologias reprodutivas, baseandose em descobertas recentes da genética, da embriologia, da bioquímica, das tecnologias reprodutivas com animais, tudo isso objetivando o melhoramento da espécie humana. Num futuro próximo, se seguidas as diretivas transumanistas, a doença e a morte seriam abolidas. Para Haldane, a ciência é a "conquista gradual, primeiramente do espaço e tempo, depois da matéria como tal, então seu próprio corpo e daqueles outros seres vivos, e finalmente a subjugação dos elementos negros e maus em sua própria alma" (HALDANE, 1923, 82). A afirmação que ele faz em sua coletânea de ensaios "Possible Worlds and other essays", de que "a doença é somente uma falência corporal para se ajustar ao ambiente" (HALDANE, 2000, 187), seria repetida por transumanistas no século XXI, como Yuval Harari.

A ciência possuiria as chaves do progresso moral e se a "humanidade conseguir ajustar sua moralidade com seu poder", o futuro será auspicioso. Precisamos de uma nova moral. E foi nesse sentido que Julian Huxley direcionou seus escritos ainda na década de 1920. Julian foi um renomado biólogo, professor em Oxford e popularizador da ciência, chegando a ser presidente da Unesco e tendo papel importante na comissão que redigiu a carta dos direitos humanos (DEESE, 2015, 19-22). Em 1951 ele cunhou o termo transumanismo para indicar o conjunto de valores éticos e científicos que seus colegas cientistas estavam propondo. Em suas palavras:

Talvez seja melhor chamar uma filosofia tão ampla, não de Humanismo, porque tem certas conotações insatisfatórias, mas de Transumanismo. É a ideia da humanidade tentando superar suas limitações e chegar a uma fruição mais plena (HUXLEY, 1951, 140).

Mas o que seria essa "fuller fruition" ficava um tanto vago nos escritos desses pensadores, variando as aplicações técnicas e o objetivo final. Mesmo assim, o que fica evidenciado é que só a ciência seria capaz de amplificar a natureza humana elevando o homem a um "plano maior" (HUXLEY, 1969, 71); agora o homem consegue obter controle total da natureza e modelar os passos da evolução de acordo com sua vontade. É isso que Julian afirma em seu artigo de 1975, "New bottles for new wines" [Odres novos para vinhos novos]: 
A espécie humana pode, se quiser, transcender a si mesma não apenas esporadicamente, um indivíduo aqui de uma forma, um indivíduo ali de outra - mas em sua totalidade, como humanidade [...] o homem permanecendo homem, mas transcendendo a si mesmo, realizando novas possibilidades de e para sua natureza humana (HUXLEY, 1968, 76).

O título da publicação remete à parábola de Jesus que se referia à conversão ao evangelho. Julian perverte a parábola para apontar a visão transumanista: nova consciência em novos corpos. Assim, a questão da mente sempre está presente nestes debates. Para Julian, a "exploração da mente" rivalizaria com a exploração espacial, "transcendendo [...] o domínio das realidades materiais, um mundo de satisfações que superam a satisfação física de forma mais absoluta e perfeita" (HUXLEY, 1977, 145). A evolução desejada levaria à uma "divinização da existência" (HUXLEY, 1977, 146), ao "Homo deus" (HARARI, 2016).

As ideias de Julian estavam ancoradas na obra "O fenômeno humano" do padre e paleontólogo Teilhard de Chardin, para o qual os seres humanos atingiriam um estágio futuro de evolução denominado "ultra-hominização". O homem é um ser incompleto e, portanto, deve tomar as rédeas da evolução para alterar e acelerar seu desenvolvimento. A convergência humana final tenderia para o ponto Ômega, quando houvesse uma unificação das mentes e se alcançasse uma organização "hiperpessoal" (HUXLEY, 1977). A interferência humana para conduzir esse processo deve se direcionar à cabeça, num processo de "cefalização", enfatizando o cérebro em detrimento de outras partes do corpo humano.

Essa ênfase no cérebro humano como auge da evolução é uma inclinação natural dos transumanistas de ontem e de hoje. Outro pensador que forneceu as bases do movimento, o físico John Desmond Bernal, foi o que mais escreveu nesse sentido. Em 1929 ele escreveu o ensaio "The World, The Flesh and the Devil" [O mundo, a carne e o diabo], em que assinalava que "Os homens não se contentarão em fabricar a vida: eles irão querer melhorá-la" (BERNAL, 1970, 20). O objetivo principal do projeto de Bernal era o "homem mecanizado". Assim, na parte que se refere à "carne" em seu texto, ele propõe que a maior parte do corpo humano natural orgânico seja paulatinamente substituído por partes mecânicas. Em uma passagem que demonstra a filosofia puramente fisicalista, isto é, que compreende o ser humano como completamente físico, Bernal $(1970,20)$ diz que "Afinal é o cérebro que conta, e ter um cérebro inundado por sangue fresco e corretamente prescrito é estar vivo - é pensar".

Esse raciocínio reverbera a noção da filosofia platônica de uma alma ideal, em que se encontra a essência humana genuína, e que está 
aprisionada a um corpo de natureza animal, material, assim permanecendo "até a hora em que o próprio Deus aprouver libertar-nos", momento em que "então, a insensatez do corpo será afastada e nós seremos puros e interagiremos com outras almas puras" (PLATO, 1973, 498). Não por outra razão, Platão entendia haver uma oposição entre as finalidades humanas e os seus desejos carnais. Nessa perspectiva, que representa uma espécie de personalismo dualista, "o meu corpo é, em alguma dimensão, externo a mim, porque eu sou, nessa visão, o que pode ser chamado de uma 'pessoa incorpórea', ou uma 'mente habitando um corpo'" (GÓMEZ-LOBO; KEOWN, 2015, 31).

Assim o corpo seria algo a ser descartado em nome da evolução; a mente e sua interação com o corpo é algo que não importaria. Deste modo, ele descreveu que poderíamos ir substituindo os nervos e órgãos por mecanismos: olhos por raios ultravioletas, ouvidos por detectores supersônicos capazes de detectar altas e baixas temperaturas, controle de objetos através da simples vontade. Esse processo seria iniciado em "fábricas ectogenéticas", onde o homem hibernaria até atingir o próximo ponto na evolução, quando o cérebro humano fosse instalado em um cilindro (BERNAL, 1970, 15).

Por fim, com o cérebro nesse corpo mecanizado, os novos órgãos substituiriam os nossos sentidos limitados alargando enormemente nossas capacidades sensoriais. O próximo passo na evolução seria uma interligação de cérebros e através dessa coletividade algo como a imortalidade seria alcançada. Os cientistas então se entregariam à busca da autoconsciência cósmica (a noção de Chardin).

Temos aqui esboçadas as origens do movimento transumanista e sua preocupação com o aperfeiçoamento humano, que passava pelo aprimoramento do cérebro humano, sendo este o último reduto e ápice da evolução.

Já no momento em que eram concebidas estas ideias surgiram críticas. Mesmo materialistas como Bertrand Russell viam com desconfiança o projeto transumanista. No panfleto resposta à Haldane, Russell, em uma referência ao título do texto de Haldane, Dédalus, utilizou a metáfora de Ícaro para apontar para as limitações do método científico, ainda mais quando se referia à projetos científicos de transformação social que utilizavam técnicas industriais, biotecnológicas e psicológicas (RUSSEL, 2009; MARTINS, 2012, 374; RUBIN, 2005, 73).

Um dos maiores críticos desses momentos iniciais do transumanismo foi C. S. Lewis. Lewis foi professor de literatura em Oxford e escreveu diversos textos de ética. Em sua série de ficção científica "A trilogia cósmica" e em seu texto bastante influente "A abolição do homem" abordou o tema 
do transumanismo. Lewis acusou fortemente esse movimento de eugenista, algo que os próprios proponentes não negavam, e até defendiam. Haldane argumentou nesse sentido em diversos textos - especialmente no capítulo eugenics and social reform (HALDANE, 2000) -, mesmo Julian jamais negou, ao contrário continuou enfatizando após a Segundo Guerra Mundial (HUXLEY, 1977). Lewis também criticava esse movimento de ser reducionista e de cercear a liberdade humana. Ele transpôs essas ideias em formato de ficção científica em sua Trilogia Cósmica para procurar alcançar um público maior. E teve resultado, tendo até cientistas ateus comentando sobre os livros. Haldane se deu o trabalho de resenhar a trilogia, criticando o posicionamento anti-ciência de Lewis (HALDANE, 2017, 249-258). Em uma carta resposta à Haldane, Lewis respondeu:

Minha trilogia cósmica "certamente é um ataque, não aos cientistas, mas algo que podemos chamar de "cientificismo" - uma certa perspectiva do mundo que está normalmente conectada com a popularização da ciência [...] Em outras palavras, a crença de que o objetivo moral final é a perpetuação das espécie, e de que ela deve ser perseguida mesmo que [...] nossa espécie tenha que ser despojada de todas as coisas que nós valorizamos - a piedade, a alegria, e a liberdade (LEWIS, 2009, s.p.).

Os transumanistas seriam reducionistas por acharem que a matéria era tudo que existe, que o ser humano pode ser melhor compreendido pelo estudo e aperfeiçoamento do cérebro, deixando de lado a relação do corpo com a realidade; também seriam reducionistas por imaginarem que a ciência pudesse dar cabo de explicar toda a natureza humana, cabendoIhes a acusação de cientificistas. Lewis atacou a cosmovisão materialista e gnóstica da natureza humana por parte dos transumanistas, segundo a qual o corpo é algo ruim que deve ser deixado para trás na busca pelo próximo passo da evolução. Também fazia uma crítica a um anseio de que o artificial seria superior ao natural, como uma posição tecnicista.

Lewis apontava que através da união da eugenia com a tecnologia ocorreria a inevitável abolição do homem:

O último estágio virá quando, mediante a eugenia, a manipulação pré-natal e uma educação e propaganda baseadas numa perfeita psicologia aplicada, o Homem alcançar um completo domínio sobre si mesmo. A natureza humana será a última parte da Natureza a se render ante o Homem. A batalha estará então vencida. Teremos "arrancado o fio da vida das mãos de Cloto" e, daí por diante, seremos 
livres para fazer da nossa espécie aquilo que desejarmos. A batalha estará definitivamente vencida. Mas a pergunta é: quem exatamente a terá vencido? (LEWIS, 2017, 59).

Assim, ele alertava que "o que chamamos de poder do Homem sobre a Natureza, revela-se como o poder exercido por algumas pessoas sobre as outras, tendo a Natureza por seu instrumento" (LEWIS, 2017, 59). A acusação de Lewis era de que o transumanismo não buscava - nem redundava em - liberdade, mas sim em determinação por parte de alguns do que seria o curso a ser seguido; e todos deveriam seguir, sob pena de ficarem para trás. Aliás, uma crítica que viria a ser comum pelos opositores do liberalismo defendido por John Rawls.

A aparente liberdade de se escolher aperfeiçoamentos a partir da bioengenharia desde o início implica uma delimitação do que é superior ao que é inferior, criando uma separação entre melhorados e não melhorados. Para Lewis, a natureza humana é algo que não devemos modificar completamente, sob pena de perder algo valioso. Ele não era contra melhoras e restituição do funcionamento dos órgãos; tendo vivido duas guerras ele sabia a importância da medicina e da ciência para aliviar sofrimentos. Mas ele era um crítico da arrogância de que alguns homens sabiam exatamente qual o caminho que a evolução deveria seguir para se atingir um nível superior. Ele buscou mostrar em textos acadêmicos, ensaios e até em literatura o absurdo da busca transumanista e em como seus proponentes questionaram eticamente muito pouco suas intenções.

Estas ideias de Lewis chamaram a atenção de Hans Jonas quando este pensava sobre as implicações da genética e da clonagem humana em um livro de 1974, antes mesmo de ter escrito seu conhecido "O princípio responsabilidade" de 1979 (JONAS, 2006). Jonas apontou que as questões de poder relacionadas à biologia moderna se encontravam numa "exposição mais precisa [...] no excelente livro de C. S. Lewis 'A abolição do homem"" (JONAS, 2013, 178). Ambos perceberam que essa busca por controle sinalizava o controle de algumas centenas de homens do destino de bilhões. Lewis e Jonas estavam preocupados com o sempre crescente desejo humano de controle e manipulação da natureza, mas agora potencializado pelas inovações da biotecnologia. Num puro espírito baconiano, os homens têm produzido instrumentos através da ciência e da tecnologia para interferir na constituição genética do homem, buscando direcionar os próximos passos da evolução humana.

Jonas afirmou que com a "técnica biológica" ocorreu um rompimento com a divisão moderna que estabelecia que o homem era o sujeito e a natureza o objeto técnico. Agora, o homem torna-se objeto direto, passível 
de ser manipulado e modificado. Mas o objeto que surgirá dessas modificações, o extra-humano ou o transumano, estará sob o poder dos planejadores atuais. Porque os novos seres humanos que porventura surgirem não escolherão que características desejavam e deverão se fiar na pretensa sabedoria de seus progenitores. Este domínio para Jonas também é um poder cego na medida em que, devido à falibilidade e limitação humanas, não se pode prever todas as implicações de se manipular a natureza humana.

Ainda no contexto de Lewis, outro importante filósofo da ciência levantou questionamentos quanto à limitação das proposições transumanistas de aprimoramento. Michael Polanyi foi um físico-químico polonês, que migrou para a Inglaterra e se tornou filósofo, principalmente após perceber o que a ciência planejada estava causando na URSS. Para ele, o problema do cientificismo presente em movimentos como o transumanismo pecava por tratar o ser humano de forma reducionista. Queria-se desenvolver a mente humana, mas a neurociência ainda estava engatinhando e ninguém sabia definir o que era a inteligência humana. Também ele via com suspeita a própria ideia de que algum dia existiria uma inteligência artificial que superaria a inteligência humana, acusando os estudiosos do campo de esquecerem que o ser humano é mais do que seu cérebro.

Para Polanyi, mesmo que um dia conseguíssemos analisar todas as sinapses cerebrais, todo o funcionamento do cérebro (algo que ele duvidava), ainda assim não teríamos a explicação do que é a mente humana. Isso porque somos mais do que nossos cérebros. Polanyi argumentava que a vida humana não pode ser totalmente descrita em termos científicos, e postulava que o homem possui uma natureza hierárquica. No nível fundamental, os seres humanos são seres físicos. Além desse nível fundamental, os humanos também possuem níveis fisiológicos, intelectuais e morais que não podem ser explicados pela física e pela química (e ele era químico), nem reduzidos a somente um campo. Ele afirmava que:

[...] é tão sem sentido representar a vida em termos de física e química, como interpretar um relógio de pêndulo ou um soneto de fala de Shakespeare em termos de física e química, e também é inútil representar a mente em termos de uma máquina ou de um modelo neural (POLANYI, 2009, 382).

A impossibilidade de uma Inteligência Artificial emular completamente o pensamento humano é reconhecida como o paradoxo de Polanyi (COLLINS; KUSCH, 2016). A discrepância entre o pensamento humano e os 
algoritmos de aprendizagem das IAs gera uma dificuldade para automatizar certas tarefas que demandam senso comum, como por exemplo, flexibilidade, adaptabilidade e julgamento, elementos constitutivos do conhecimento intuitivo humano (POLANYI, 2009, 55, 263). Além disso, Polanyi também enfatizou diversas vezes a importância do corpo na compreensão do ser humano. Somos seres que possuem cérebros e que precisam de todos os órgãos para funcionar e para se relacionar com a realidade externa. Isolar o cérebro do corpo, como alguns transumanistas propunham, é um grande erro .

Então, falar de aprimoramento neurocognitivo seria uma forma reducionista e mecanicista de encarar a vida humana, porque retira a riqueza múltipla do que é o humano ao focar somente na materialidade da vida e do que se pode matematizar.

\section{A atual busca transumanista por aprimoramento cognitivo}

Desde o início, o movimento moderno do transumanismo tinha uma percepção sobre o bem comum. O humanismo de Haldane, Julian Huxley e Bernal pressupunha que o aperfeiçoamento do ser humano era uma obrigação moral para sobrevivermos na competição evolutiva. E para se atingir os objetivos de transcender as limitações humanas, através da tecnologia e da ciência, deveria ser encaminhada uma centralização das políticas nesse sentido. A liberdade de escolha poderia ser cerceada em busca de um bem maior.

Em 1963, em um evento da Fundação britânica Ciba, que procurava divulgar pesquisas em medicina e química - em que estavam presentes Julian Huxley J. B. S. Haldane e Peter Medawar -, o neurocientista estadunidense Hudson Hoagland conectou de maneira bastante clara a questão de aperfeiçoamento e bem comum. Para ele, o controle de comportamento através de intervenção neurológica (fármacos ou cirurgia cerebral), seria um passo importante para diminuir os males da humanidade e favorecer o bem comum (WOLSTENHOLME, 1963, 299-314). O futuro da mente, em uma perspectiva evolutiva, transumanista e eugenista foi discutida em outras mesas nesse mesmo evento.

O movimento mais atual do transumanismo possui suas raízes no movimento inglês da primeira metade do século $X X$ e tem, dentre seus representantes, que também trataram de questões de aprimoramento e neurocognição, Raymond Kurzweil, Nick Bostrom, Ingmar Persson e Julian Savulescu. Com as inovações na pesquisa de neurociência e biotecnologia a partir da década de 1980, a preocupação com a ética assim como limites e possibilidades de aperfeiçoamento fervilhavam. O livro de Kurzweil, "A 
era das máquinas espirituais" (2007) apontou para um futuro de mentes desconectadas de corpos, mas ele não discute limites morais e éticos, apesar de argumentar que procura tratar das promessas e dos perigos. Em "A singularidade está próxima" ele afirmou que a moral contra possibilidades transumanistas de transfusão de cérebros é algo que deve ser superado. Não há preocupações com o bem comum (KURZWEIL, 2018). São os outros autores que iriam abordar essas limitações ao defenderem o aperfeiçoamento neurocognitivo.

Ingmar Persson e Julian Savulescu - ambos professores no centro Uehiro, alocado na universidade de Oxford e voltado para a Ética Prática -, defendem que a natureza humana não é equipada com uma psicologia moral robusta para lidar com novos problemas morais decorrentes de novas tecnologias. Assim, argumentam que devemos agir no sentido de um melhoramento moral possibilitado pelas técnicas da genética e da neurobiologia. A preocupação desses autores é no sentido de viabilizar igualdade de oportunidades e de tornar a natureza humana menos egoísta e mais sensível a preocupações igualitaristas (PERSSON; SAVULESCU, 2017 , 74). Mas eles são cautelosos com as intervenções de melhorias e sabem do risco de soluções puramente tecnicistas, propondo uma maior preocupação com o bem comum.

As inquietações principais de Persson e Savulescu resumem-se em que "sem a disposição para sacrifícios pessoais em favor de indivíduos em países remotos e num futuro remoto", então "o mais provável é que não haja o mínimo de esforço para desenvolver-se e utilizar-se uma tecnologia que poderia interromper ou minimizar significativamente a degradação climática e ambiental antropogênicas" (PERSSON; SAVULESCU, 2017, 154). Para ajudar a solucionar devemos investir em aprimoramento moral através de biotecnologia, para que tenhamos sabedoria para resolver os problemas humanos e ambientais. Uma vez que características como altruísmo e senso de justiça possuem bases biológicas, já temos conhecimento disponível para interferir e ampliá-las. O senso de bem comum seria ativado e amplificado através da biotecnologia.

Confrontando uma crítica comum aos transumanistas, Persson e Savulescu $(2017,166)$ afirmam que o melhoramento moral não restringe a liberdade individual, uma vez que ele tornaria o sujeito mais capaz de vencer os impulsos negativos e direcionar seus atos ao que é moralmente bom. Entretanto, os autores têm consciência de que há perigos no aprimoramento, ecoando preocupações caras a Hans Jonas (JONAS, 2006), por exemplo:

[...] é mais fácil para nós prejudicar do que beneficiar, pois mudanças em sistemas complexos geralmente são mais 
prováveis de serem para o pior do que para o melhor. É, portanto, racional ser cauteloso quanto à mudança de uma situação corrente para algo novo e, quanto mais radical a mudança, mais cauteloso deve-se racionalmente ser, devido ao risco maior de efeitos inesperados (PERSSON; SAVULESCU, 2017, 168).

Ainda assim, os autores não enxergam um panorama pelo qual se consiga fazer com que todos sejam motivados a fazer o que é bom através da educação ou instrução; por isso propõem o melhoramento moral através de medicamentos.

Enfim, Persson e Savulescu partem da premissa de que o altruísmo e o senso de justiça são algo natural, presente no cérebro humano, portanto, passível de ser amplificado através de medicamentos. Isso é uma pressuposição puramente materialista e naturalista. Em uma leitura cínica do altruísmo, o filósofo da biologia Michael Ruse e o biólogo Edward 0 . Wilson dizem:

Moralidade, ou mais estritamente, nossa crença na moralidade, é meramente uma adaptação posta em prática para promover nossos fins reprodutivos. Uma vez que a base da ética não reside na vontade de Deus [...] ou em nenhuma outra parte da estrutura do universo. Em um sentido importante, ética [...] é uma ilusão embutida em nós pelos nossos genes para nos fazer colaborar (RUSE; WILSON, 1985, 50-52).

Se levada ao extremo uma visão puramente evolutiva-naturalista, o bem comum seria um retrocesso evolutivo, uma vez que possuímos "genes egoístas" que se preocupam unicamente com a propagação da espécie (DAWKINS, 2014). E se o melhoramento moral bioquimicamente dirigido levasse a um aumento da marca evolutiva do egoísmo, ao invés do bem comum? Mesmo sabendo exatamente que partes do cérebro ativar ou aperfeiçoar para tornar o ser humano mais altruísta, não podemos ter certeza de que teríamos um bom resultado, porque não temos como prever os rumos evolutivos no longo prazo.

O filósofo Nick Bostrom é professor de filosofia em Oxford e diretor do "Future of Humanity Institute", uma instituição de pesquisa estabelecida na mesma universidade e, como o nome aponta, voltada a pensar o florescimento humano de longo termo. Bostrom propõe desenvolver a superinteligência tendo no horizonte o bem comum. Segundo ele, "Uma superinteligência deverá ser desenvolvida para o benefício de toda a 
humanidade e a serviço de ideais éticos amplamente compartilhados por todos" (BOSTROM, 2018, 457). Ele propõe manipulação genética assim como aprimoramento cognitivo como ferramentas para que o ser humano evolua e sobreviva. O que é merecedor de ênfase é que, mesmo sendo transumanista, Bostrom apontou as possibilidades de erros em buscar uma superinteligência, como o exemplo mais clássico da Inteligência artificial fabricante de papel: "Uma IA projetada para gerenciar a produção em uma fábrica recebe como objetivo final a maximização da produção de clipes de papel, e em seguida converte primeiro a Terra e então partes progressivamente maiores do universo sustentável em clipes de papel" (BOSTROM, 2018, 232).

Essa "profusão de infraestrutura", como Bostrom denominou, é um caso pertinente para se pensar quão vagas são as nossas noções do que realmente compreendemos por bem comum. Sem uma base sólida e objetiva acerca do bem comum (como veremos à frente) é difícil conduzir o desenvolvimento tecnológico com essas intenções.

O que fica dos transumanistas são boas intenções com relação ao bem comum e ao aprimoramento cognitivo, mas que acabam escorregando na aplicação prática por não possuírem uma boa definição do que seria esse bem comum e por falharem em perceber as complexidades da mente humana e como esta se relaciona com o corpo. Poderíamos pensar que talvez o bem comum nas décadas e séculos à frente seja levar à extinção certa raça de seres devido à sobrevivência dos mais aptos. Ou que retirar o cérebro do casulo que é o corpo humano, como almejam alguns transumanistas, dê errado por não levar em consideração a complexidade da relação corpo-mente.

O movimento transumanista já foi acusado muitas vezes de ser eugenista, e essa busca de melhoramento cognitivo levanta questionamentos. O que seria exatamente o bem comum para os transumanistas? E mesmo que se dê uma resposta satisfatória à essa pergunta, os meios científicos e tecnológicos seriam a melhor forma de atingir isso? O corpo é algo que pode ser manipulado ao bel prazer e, em caso de equívocos, ser retornado à condição prévia de funcionamento?

\section{Crítica ético-social ao transumanismo}

A preocupação em relação aos problemas éticos que podem advir de uma revolução transumana é compartilhada por autores contemporâneos como Habermas (1997; 2004), Fukuyama (2002), Kaas (2003) e Sandel (2013), os quais suspeitam das profecias triunfalistas exaltadas por entusiastas do movimento transumanista. Autores desse viés têm sido 
frequentemente taxados - às vezes de forma pejorativa - de bioconservadores. Todavia, uma revolução tão profunda como essa não pode prescindir de uma ponderação cautelosa de suas possíveis implicações. Além disso, uma reflexão ética que seja posterior às modificações transumanas pode se mostrar extemporânea, sendo importante que se operem tais considerações de forma prévia, com vistas a desenvolver critérios éticos que sejam aptos a balizar a própria produção dessas inovações, a fim de impedir não apenas o surgimento de avanços injustos, como também para assegurar que as finalidades da produção científica sejam elas próprias éticas (BUCHANAN, 2011).

Um dos principais dilemas suscitados no debate, principalmente por autores situados nas tradições bioéticas substancialista e personalista, diz respeito às implicações morais de uma alteração radical no estatuto especista humano. Tal questão é especialmente problemática quando temos em vista que as concepções contemporâneas de direitos humanos possuem, ao menos implicitamente, uma fundamentação naturalista (FINNIS, 2007; MARITAIN, 1966; DOUZINAS, 2000), sendo, portanto, contingentes à natureza humana enquanto tal. A questão que costuma ser suscitada é: e se a natureza humana for modificada a tal ponto que Ihe sejam inaplicáveis atributos atualmente vinculados àquela natureza, como o ideal de direitos humanos? (FUKUYAMA, 2002; KAAS, 2003). Por outro lado, e se tais modificações trouxerem tal nível de capacidades elevadas às pessoas aprimoradas que lhes seja outorgado um status moral superior ao dos demais seres humanos? (BUCHANAN, 2011). Para se concluir que tais preocupações não são meramente especulativas, basta observar a proximidade temporal de episódios bárbaros como o Genocídio de Ruanda, a própria $2^{a}$ Guerra Mundial e a emergência atual de movimentos nazistas/racistas de extrema direita.

Essa suspeição é especialmente relevante no que tange aos melhoramentos neurocognitivos, eis que há possibilidade, segundo previsões de autores ligados ao movimento, de aprimoramentos mesmo na ordem moral e intelectual do ser humano (BOSTROM; SAVULESCO, 2009). Como um exercício hipotético, pode-se imaginar um parlamento cujos membros, mediante interfaces neurocibernéticas que lhes sejam implantadas, sejam capazes de, em questões de segundos, calcular com precisão os resultados de cada um dos cursos de ação em debate. Em que pese, por um lado, tal cenário poder parecer interessante ao bem comum, por outro, pode-se questionar se seria possibilitada a participação democrática de pessoas que optem por não realizar tais implantes. É possível, portanto, prever facilmente a restrição à participação política de 
indivíduos não melhorados, os quais seriam considerados desprovidos das habilidades necessárias à gestão pública.

Sobre essa problemática, Buchanan (2011) argumenta que essa celeuma não se restringe aos aprimoramentos neurocognitivos, decorrendo, antes, de uma ótica elitista que independe dos avanços transumanistas, radicada no clássico argumento, de origem platônica, de que apenas os mais inteligentes devem governar. Sem embargo, é inevitável reconhecer que a problemática, se não criada pelo transumanismo, certamente por ele seria agravada. Enquanto o caminho recente da humanidade tem sido no sentido de reconhecer o direito à participação política de todos, o surgimento de distinções tão profundas entre as pessoas certamente reacenderia discursos de jaez aristocrática.

O que se visualiza é que o transumanismo pressupõe a crença de que os desenvolvimentos tecnológicos no campo biocientífico conduzirão a um aprimoramento não apenas intelectual, cognitivo e funcional, mas também moral. Com efeito, subjazem a essa perspectiva premissas que não são de modo algum inéditas. Trata-se, antes, da retomada da noção moderna, radicada na revolução iluminista, de que o progresso científico da humanidade seria inevitavelmente acompanhado de um avanço moral (VILAÇA; DIAS, 2014, 347). Nessa concepção, "o progresso não é um acidente, mas uma necessidade. Certamente o mal e a imoralidade devem desaparecer; certamente a humanidade deve se tornar perfeita" (SPENCER, 1892, 32).

Não obstante, como questionado por Vilaça e Dias (2014, 349), embora o transumanismo pressuponha que "tudo está na biologia, de modo que alguns desafios de outras ordens [...] seriam solucionados biologicamente", é certamente plausível que "benefícios biológicos individuais (por exemplo, extensão da vida de alguns) possam gerar problemas coletivos graves (por exemplo, escassez de suprimentos)".

Deve-se aprender com o passado e assumir que, após duas Guerras Mundiais, o otimismo em relação ao projeto Iluminista de construir um novo edifício moral a partir do cientificismo racionalista foi severamente abalado, especialmente ao se perceber que as ideias eugenistas do Terceiro Reich valeram-se fortemente das teorias darwinistas. Mais do que um mero regime totalitário dentre tantos outros na história da humanidade, o projeto nazista é uma demonstração histórica emblemática do problema da transposição imediata de critérios científicos para o campo da ética. Como bem lembra o sobrevivente do Holocausto Viktor Frankl $(1989,45)$, "não foram apenas alguns ministérios de Berlim que inventaram as câmaras de gás de Maidanek, Auschwitz, Treblinka", antes, "elas foram preparadas nos escritórios e salas de aula de cientistas e filósofos niilistas, entre os quais 
se contavam e contam alguns pensadores anglo-saxônicos laureados com o Prêmio Nobel".

Deve-se ponderar, ainda, as implicações no contexto do sistema socioeconômico capitalista, pois, como aponta Habermas $(1997,73)$, há no capitalismo tardio uma junção íntima entre técnica e ciência, criando "uma perspectiva na qual a evolução do sistema social parece estar determinada pela lógica do progresso técnico-científico". Isso conduz a uma inevitável valoração distinta das características humanas, o que Lewis (2017) chama de "abolição do homem". Vilaça e Palma $(2012,1026)$ ressaltam que, invariavelmente, "contígua aos juízos de fato, há a presença de juízos de valor a partir dos quais é escolhido o que deve constituir a natureza humana, distinguindo o que deve ser combatido ou promovido, o 'mal' e o 'bem'", e exemplificam que doenças e deficiências que são "características naturais, logo, inerentes à condição biológica do humano", ainda assim, "são tidas como índices de precariedade e imperfeição, sendo consideradas males".

Há uma séria probabilidade de que esta categorização seja feita segundo critérios funcionalistas submetidos à economia de mercado, implicando uma veridição mercadológica da ciência, como se visualiza na relação questionável entre pesquisas farmacológicas e grupos econômicos. Considerando que a agenda das pesquisas farmacêuticas é determinada pela demanda de mercado e pela influência política de grupos atuantes nos países desenvolvidos em que essas companhias estão sediadas, é verossímil esperar que avanços médicos que poderiam salvar milhões de vidas em países menos desenvolvidos, sem o mesmo poder de compra, nunca sejam produzidos (BUCHANAN, 2011, 246).

Alguns autores observam que, já no presente, pode-se observar a existência de lógica elitista e excludente nos estudos transumanistas, já que - capital arrecadado para seu financiamento representa "uma forma de concentração de bens nas mãos de poucas instituições e pessoas", e que os benefícios hipotéticos dessas pesquisas, determinam "a morte real de famintos e migrantes e uma seleção indireta de indivíduos aptos ao prolongamento da vida ou à pretensão da imortalidade" (HAMMES, 2014, 449). Não por outra razão, o próprio Papa Francisco, em sua mensagem ao Fórum Econômico Mundial de 2018 "apelou para o emprego adequado de tecnologias que estão associadas aos projetos trans- e pós-humanistas" (HAMMES, 2014, 447), defendendo que estas "devem ser empregadas de modo que contribuam para o serviço da humanidade e para a proteção da nossa casa comum" (FRANCISCO, 2018, s.p.).

Sem embargo, os riscos de uma economização capitalista dos aprimoramentos transumanistas não são mera especulação de 
"bioconservadores", encontrando expressão clara nas propostas atuais de alguns pensadores do movimento, como a teoria de Robert Nozick (1974, 315), que defende a formação de um "supermercado genético", em que genitores poderiam, diante de uma série de características fenotípicas, optar por aquelas que desejam para seus filhos. Considerando que a hierarquização de traços genéticos segundo sua desejabilidade (demanda) conduziria a uma valoração financeira desigual dentre eles, seguir-se-ia que apenas as famílias com maior capacidade aquisitiva poderiam escolher os genes socialmente melhor estimados, no que parece ser o ápice da biopolítica foucaultiana. Assim, as inovações transumanistas apresentam um potencial inédito de dimensionar desigualdades interpessoais, uma vez que transportam esse desequilíbrio dos campos econômico e social para o próprio âmbito de constituição substantiva do sujeito, efetivamente transmutando seu estatuto ontológico e ressignificando, nesse processo, seu valor moral e social.

Isso tem implicações relevantes para a própria liberdade individual. "A liberdade pessoal é também a liberdade da outra pessoa e é mutuamente constitutiva", o que implica que "a manipulação genética - pode dizer-se também transumanizadora - potencialmente rompe a liberdade de outrem, na medida em que pode condicionar essa mesma liberdade no próprio sujeito ou nos demais sujeitos" (HAMMES, 2014, 444). Logo, mesmo sob um panorama sociológico de cunho liberal, permaneceriam as condicionantes desigualizadoras, mormente quando se observa que as estruturas biopolíticas do capitalismo tardio utilizam não mais os mecanismos coercitivos expressos no antigo modelo punitivo (fazer morrer, deixar viver), mas sim uma dinâmica de incentivos hierarquizados (fazer viver, deixar morrer):

[...] no caso de aprimoramentos que prometem maior produtividade, a preocupação, ao menos em Estados com uma 'cultura de direitos', pode ser não uma ação estatal coercitiva (esterilização compulsória ou seleção genética compulsória de embriões humanos), mas sim o subsídio estatal e o encorajamento social a que o indivíduo submetase a apimoramentos. Essa eugenia 'mais suave', não coercitiva, sustentar-se-ia em outras forças que encorajam o recurso aos melhoramentos. A combinação de encorajamento estatal, marketing [sic] privado vigoroso e uma 'mentalidade de rebanho' da cultura popular podem resultar em uma situação em que os indivíduos possuem mais escolhas, mas de uma forma negativa. Por exemplo, mesmo que o Estado não force as pessoas a usarem tecnologias para produzir embriões 'melhores', muitas pessoas podem se sentir 
compelidas a fazê-lo, diante de subsídios governamentais e a pressão social de evitar-se uma prole 'abaixo do padrão' (BUCHANAN, 2011, 22).

Esmaece, assim, a linha que separa o poder e o dever, já que se pode facilmente prever uma pressão estrutural contra os não melhorados, implicando um condicionamento da liberdade individual. Exemplificativamente, caso um indivíduo "não aplicasse as biotecnologias na constituição da sua descendência (liberdade reprodutiva), e caso esta desenvolvesse algum problema de saúde evitável, sua condenação moral seria quase que incontornável" (VILAÇA; PALMA, 2012, 1035). Como salienta Sandel (2013, 118-120), considerando que "é papel dos pais promover o bem-estar dos filhos [...], tais melhoramentos não se tornam somente aceitáveis, mas obrigatórios", e "da mesma forma que o governo pode exigir que os pais mandem os filhos para a escola, pode exigir que eles utilizem tecnologias genéticas (desde que seguras) para aumentar o QI dos filhos".

Tais ponderações permitem a compreensão de que há dilemas éticos complexos sobre os quais se deve refletir cautelosamente e que devem tanto preceder quanto balizar os aprimoramentos neurocognitivos.

\section{Os bens humanos em face do transumano}

Para explicar a ética comunitária de filósofos políticos como Sandel (2013) e Taylor (2011), que, ao lado de filósofos morais como MacIntyre (2007) e teóricos sociais como Finnis (2007), embasam a argumentação deste artigo, Kymlicka (2006, 279) advoga a necessidade de "fóruns compartilhados" para se debater, constantemente, a estrutura cultural que torna significativa as escolhas individuais, pois "a participação em práticas linguísticas e culturais compartilhadas é o que capacita os indivíduos a tomarem decisões inteligentes a respeito da boa vida" (KYMLICKA, 2006, 285). Sem isso, é impossível falar-se de um verdadeiro bem comum.

O ideal de bem comum é um conceito-chave na filosofia clássica, sendo, nessa tradição, a própria raison d'être do Estado. É a promoção do bem comum que justifica e legitima a autoridade do Estado de Direito (FINNIS, 2007). Jacques Maritain (1966, 54), outro neoaristotélico notório, explica que a função do Estado "não é garantir a conveniência material de indivíduos esparsos, cada um absorvido no seu próprio bem-estar e enriquecendo a si mesmo", nem "promover o domínio industrial sobre a natureza, ou o domínio político sobre outros homens", mas, antes, "melhorar as condições de cada vida humana em si" e "procurar o bem 
comum da sociedade", e isso "não apenas em uma classe privilegiada, mas por toda a coletividade".

É importante salientar que essa concepção comunitarista é fundamentalmente distinta daquela presente nas sociedades prémodernas, com sua lógica homogeneizadora que suprimia as identidades particulares. O bem comum neoaristotélico "nem afirma, nem acarreta que os membros de uma comunidade devam todos ter os mesmos valores ou objetivos (ou um conjunto de valores ou objetivos)", mas sim que "deve haver algum conjunto (ou um conjunto de conjuntos) de condições que precisa se dar para que cada um dos membros atinja seus próprios objetivos" (FINNIS, 2007, 156). Com isso, Finnis "supera a abstração de teorias normativas de pretensão universal" - como a de John Rawls -, que excluíam visões de mundo particulares e alberga o pluralismo razoável de formas de vida (PINHEIRO; NEIVA, 2019, 247; VALLEJO, 2013).

Isso porque o bem da razoabilidade prática equaciona a pluralidade de bens humanos, tanto no plano de vida individual de cada agente moral, como no plano social de vida, sendo este último arquitetado pelo direito, leis e políticas públicas, de que participaram ativamente todos os cidadãos, em par de igualdade, como coparticipantes de um plano, de um bem comum (SOUZA; PINHEIRO, 2020), que comporta as formas diversificadas de cada bem humano. Ora, o bem da sociabilidade pressupõe exatamente o diálogo com o outro, a alteridade das formas razoáveis de vida, a participação inesgotável dos bens básicos e das diferentes formas de instanciá-los. Por isso, esta teoria comporta várias formas de conhecimento, experiência estética, jogo ou religião, desde que pautados nos princípios da razoabilidade prática que os tornam compatíveis com o bem comum e com os direitos humanos dos demais cidadãos, que são considerados como "amigos" cívicos (BARZOTTO, 2010).

Veja-se que, nessa perspectiva, não há conflito verdadeiro entre a garantia dos bens individuais e a promoção do bem comum. Há uma compreensão dialógica da relação entre bens particulares e bem comum, que implica que a proteção dos valores de um sujeito ou grupo deve adotar caminhos que oportunizem a concretização também dos valores humanos das outras comunidades (PINHEIRO; NEIVA, 2019, 254). O bem comum aristotélico não é o bem do maior número dos indivíduos, em uma lógica utilitarista, nem uma finalidade coletiva imposta que suprima os valores das minorias, mas a consecução, na medida mais plena possível, de todas as expressões dos bens particulares (FINNIS, 2007).

Segue-se, por corolário lógico, que a definição de bem comum depende diretamente da compreensão que se tenha de quais são os bens particulares, sob pena de aquele conceito restar vazio de significado. Como 
apontam Gómez-Lobo e John Keown (2015, xx), também não basta que se oriente por princípios bioéticos como beneficência e não-maleficência, pois "qualquer aplicação desses princípios requer logicamente uma concepção prévia do 'bem' que possa fornecer critérios para determinar o que é 'prejudicial' e o que é 'benéfico'", e "se uma pessoa não tem uma compreensão clara do(s) bem(ns) humano(s), como ela pode argumentar com qualquer garantia de que sua ação planejada prejudicará ou beneficiará alguém do lado receptor de sua ação?" (GÓMEZ-LOBO; KEOWN, 2015, xx). É imprescindível, portanto, que se tenha uma teoria descritiva dos bens humanos particulares.

Para conhecê-los, Finnis emprega um instrumento filosófico aristotélico, segundo o qual, se desejamos compreender o que é bom para determinado ente, devemos compreender as suas faculdades (potências); para compreender suas faculdades, deve-se compreender as suas ações; para compreender suas ações, deve-se compreender os fins dessas ações, seus objetivos ou propósitos (telos) (ARISTÓTELES, 2013, 16-21). No caso do ser humano, Finnis considera esses propósitos como bens (ou valores), os quais representam "qualquer coisa que uma pessoa pode de algum modo desejar", ou "todo e qualquer objeto de todo e qualquer interesse" (FINNIS, 2007). O filósofo reconhece que há, de fato, uma infinitude de bens, os quais, contudo, podem ser reduzidos a valores últimos que resumiriam a totalidade das aspirações humanas: o conhecimento, o jogo, a experiência estética, a sociabilidade/amizade, a razoabilidade prática e a "religião" (FINNIS, 2007).

A limitação de formato impede uma incursão mais acurada na teoria finnisiana. Contudo, o propósito da presente exposição não é efetuar uma defesa de determinada antropologia humana, senão que apontar que, seja qual for a lista de bens adotada, ela está vinculada ao estatuto ontológico humano. Não obstante, é essencial ponderar: e se os aprimoramentos transumanos implicarem uma alteração desse estatuto ontológico, de tal modo que esses bens não mais the correspondam? Ter-se-iam duas categorias de entes, cada uma com uma lista de bens próprios: os bens humanos e os bens transumanos. Como falar em bem comum se não há um compartilhamento de bens?

Apenas a título exemplificativo, a sociabilidade é um bem básico porque o ser humano possui em si um impulso social - é um "animal político" (ARISTÓTELES, 2013). Pode-se questionar, contudo: e se os melhoramentos transumanos trouxerem a alguns tal medida de capacidade individual que se torne dispensável a socialização? E se aprimoramentos neurológicos concederem a algumas pessoas uma dimensão de prazer tal que a experiência estética e o lúdico tornem-se irrelevantes? Que tipo de 
colaboração para o bem comum pode haver sem um estatuto ontológico compartilhado? Se a fragmentação ética e a ausência de uma metanarrativa moral já ocasionaram despedaçamento da ética pública, quais consequências podem advir de uma fragmentação ontológica?

\section{Conclusão}

A noção de bem comum exposta pelos transumanistas acaba encontrando uma série de problemas tais como: a ausência de uma definição exata do conteúdo desse bem comum e dos responsáveis por defini-lo; a fragilidade da liberdade de escolha face a coações estruturais; e a sua visão utilitarista, contrária à ideia de que temos o dever moral de buscar o bem comum de todo e cada ser humano.

A instrumentalização que ocorre no sistema capitalista, segundo uma ordem mercadológica, coloca em jogo a liberdade humana, uma vez que, na temática do transumanismo e dos aprimoramentos neurocognitivos, estar-se-ia colocando certos aspectos em detrimento de outros na busca por uma suposta boa vida. Esses certos aspectos que mencionamos seriam: (a) uma visão reducionista de vida humana, um fisicalismo, pautada numa mecanização do biológico, com uma explicação científica ou tecnológica, deixando de lado outros elementos que não possam ser racionalizados; (b) critérios de eficiência, conceito que, além de sua difícil definição, suscita o questionamento de se deveríamos sequer pautar a vida humana em critérios dessa natureza.

Há muitas críticas pelos filósofos e sociólogos da tecnologia, tais como Jacques Ellul (ELLUL, 1968), para quem a eficiência é um critério bastante duvidoso para se trabalhar. Podemos dizer que o último smartphone é eficiente, ainda que ele seja bastante dispendioso para o meio ambiente e logo se torna obsoleto? Quem decide o que é mais eficiente? Ter um QI mais alto é o mais eficiente para o ser humano? Isto se liga ao fato de que (c) a visão economicista gera uma grande desigualdade, porque nem todos poderão ter acesso à essa tecnologia. Já há casos de dopagem nos esportes, que tornam os usuários tecnicamente mais eficientes que outros competidores que não fizeram uso de substâncias proibidas. Como pessoas aprimoradas cognitivamente competiriam com outros não aprimorados nas atividades que dependem de inteligência? Isso levaria à um potencial d) apartheid cognitivo, onde deveriam ser separadas as pessoas aprimoradas das pessoas não aprimoradas; e) muitos dos proponentes do transumanismo acabam incorrendo em eugenia, no sentido de que aqueles que decidirem não se aprimorarem cognitivamente, perderão potencial competitivo (DEL AGUILA; SOLANA, 2015). 
A questão que permeia esses pontos é: quem define o que é bem comum em face dos aprimoramentos cognitivos? Queremos afirmar que, sem valores objetivos e transcendentais, essa definição corre muitos riscos, que brevemente expusemos acima. C. S. Lewis, pensando sobre o poder da ciência e da tecnologia na década de 1940, afirmou que "O que chamamos de poder do Homem sobre a Natureza, revela-se como o poder exercido por algumas pessoas sobre as outras, tendo a Natureza por seu instrumento" (LEWIS, 2017, 56). Assim, os aprimoramentos transumanistas podem acarretar um domínio sobre toda a raça humana, apontando os caminhos que a evolução deveria seguir através de intervenções científicas e tecnológicas. Isso acarretaria uma "abolição do homem", pois não sabemos o que pequenas alterações podem causar a longo prazo. O imperativo ético de que somos moralmente responsáveis pelas consequências das decisões que tomamos deveria ser bem refletido antes de incorrer em mudanças cognitivas e em uma visão individualista-liberal. O homo sapiens em sua busca por se tornar um homo deus pode encontrar a sua completa abolição.

Foi justamente contra essa pretensa autonomia de escolha individual que os primeiros comunitaristas e neoaristotélicos se levantaram, criticando as limitações do liberalismo para pautar o bem comum, levando em consideração alguns valores tais como humildade, responsabilidade, solidariedade (SANDEL, 2013, 97-103). Sandel pensa na humildade que seres limitados deveriam ter face à busca por modificações tão grandes como as propiciadas pela bioengenharia. Deveríamos ser gratos à dádiva da vida e procurar utilizar os melhoramentos da ciência para restituir o funcionamento normal dos órgãos, mas ter uma heurística do medo e da responsabilidade - nos moldes de Hans Jonas (2006) - quando pensamos em procurar aperfeiçoar.

Isso porque, dada a nossa limitação, não sabemos as implicações de nossas ações aqui e agora. Sandel aponta a arrogância, a hybris presente na tendência de levar à cabo a filosofia liberal do self-made man ao limite genômico e neural. E agir com solidariedade é pensar também nos menos afortunados; porque uns mereceriam mais do que os outros na fila do aprimoramento neurocognitivo? Sabemos que o argumento da possibilidade de neuro-aprimoramento estar disponível para todos um dia não diminui desigualdades futuras (SANDEL, 2013). Pensar solidariamente, no bem comum, também é ser cauteloso no que será criado científica e tecnologicamente.

Não são valores abstraídos da ciência nem do fazer tecnológico; antes, são valores testados ao longo do tempo, desde Aristóteles, que vem sido revividos de tempos em tempos. Os cientistas precisam ter humildade epistêmica, para perceberem que a ciência não tem a resposta para todos 
os problemas humanos, mas que pode ajudar imensamente, desde que trabalhe de braços dados com as diversas disciplinas humanas, inclusive com a filosofia. Ter a responsabilidade de pensar que devemos cuidar para que as obras de nossas mãos tornem possível a sobrevivência e continuidade dos seres humanos, tendo consciência de que há grandes chances de progredir para um caminho sem volta, no caso de mudanças biológicas. Como produzir um verdadeiro florescimento humano, seja melhorando cognitivamente ou expandindo a duração da vida, é uma questão difícil para a cosmovisão libertária e utilitarista subjacente aos movimentos transumanistas. A noção de fóruns compartilhados que indicamos acima é uma boa opção para o debate em torno do que se considera eticamente favorável na busca pelo bem comum.

Iniciamos este texto citando um exemplo literária da ficção científica Flores para Algernon, que procura nos inquietar com as questões das limitações do campo científico e dos efeitos colaterais da ampliação da inteligência através de operação. Concluímos com reticências, buscando abrir e ampliar o debate, apontando que devemos levar em consideração outros valores para além do científico no que concerne ao aprimoramento neurocognitivo. A noção de bem comum, que apresentamos acima, parece um ponto de partida teoricamente viável. 


\section{Notas}

1 Mestrando em Direitos Humanos pela Universidade do Noroeste do Rio Grande do Sul (UNIJUÍ), Ijuí, Rio Grande do Sul (R.S.), Brasil. Bacharel em Direito pela Universidade Regional Integrada do Alto Uruguai e das Missões (URI), Santo Ângelo, Rio Grande do Sul (R.S.), Brasil. Oficial de Gabinete no Tribunal Regional Federal da $4^{0}$ Região. Atua nas áreas de Ética, Teoria do Direito e Filosofia do Direito. ORCID-iD: https://orcid.org/0000-0002-3975-7188; e-mail: lucasoliveiravianna@gmail.com

2 Professor do Departamento de Humanas da Universidade Tecnológica Federal do Paraná (UTFPR), Campus Toledo. Doutor em história (UFPR), atualmente pesquisa e ministra aulas sobre história da tecnologia, filosofia da tecnologia e da ciência e tecnologia e sociedade. Com residência pós-doutoral em filosofia da tecnologia na UFMG com o projeto "Em busca de transcendência: os oxfordianos e o debate em torno de ciência e tecnologia" em quem abordou o transumanismo. ORCID-iD: https://orcid.org/0000-0003-4296-2518; e-mail: luizborges@utfpr.edu.br 


\section{Referências bibliográficas}

ARISTÓTELES. Sobre a alma. São Paulo: WMF Martins Fontes, 2013.

BARZOTTO, Luiz Fernando. Filosofia do direito. Os conceitos fundamentais e a tradição jusnaturalista. Porto Alegre: Livraria do Advogado, 2010.

BERNAL, J. D. The World, The Flesh and The Devil: An inquiry into the future of the three enemies of the rational soul. 2 nd ed. Cape editions, 41 . London: Cape, 1970.

BOSTROM, Nick. Superinteligência: caminhos, perigos e estratégias para um novo mundo. Rio de Janeiro: Dark Side books, 2018.

BOSTROM, Nick.; SAVULESCU, Julian. (eds). Human enhancement. Oxford: Oxford University Press, 2009.

BUCHANAN, A. Beyond humanity? The Ethics of Biomedical Enhancement. Oxford: Oxford University Press, 2011.

CLARK, Ronald William. J. B. S.: The Life and Work of J. B. S. Haldane. London: Hodder \& Stoughton, 1968.

COLLINS, Harry; KUSH, Martin. A Forma Das Ações: O que humanos e máquinas podem fazer. Belo Horizonte: Fabrefactum, 2016.

DAWKINS, Richard. O gene egoísta. São Paulo: Companhia das Letras, 2014.

DEESE, R. S. We are amphibians: Julian and Aldous Huxley on the future of our species. Oakland, California: University of California Press, 2015.

DEL AGUILA, Jorge Walker Vásques; SOLANA, Elena Postigo. Transhumanism, neuroethics and human person. Revista de Bioética, v. 23, n. 3, p. 505-512, 2015.

DOUZINAS, Costas. The End of Human Rights. Oxford: Hart Publishing, 2000.

ELLUL, Jacques. Técnica e o desafio do século. Rio de Janeiro: Paz e Terra, 1968.

FINNIS, John. Lei Natural e Direitos Naturais. São Leopoldo: Unisinos, 2007. 
FRANCISCO, P. Mensagem do Papa Francisco ao Presidente Executivo do Fórum Econômico Mundial de Davos (Suíça). Disponível em: http://www.vatican.va/content/francesco/pt/messages/pontmessages/2018/documents/papa-francesco 20180112 messaggiodavos2018.html. Acesso em: 15 mar. 2021.

FRANKL, V. Sede de Sentido. São Paulo, Quadrante, 1989.

FUKUYAMA, F. Our posthuman future: consequences of the biotechnology revolution. New York: Farrar, Straus and Giroux, 2002.

GÓMEZ-LOBO, Alfonso; KEOWN, John. Bioethics and the Human Goods: an introduction to natural law and bioethics. Washington, DC: Georgetown University Press, 2015.

HABERMAS, J. O futuro da natureza humana: a caminho de uma eugenia liberal? São Paulo: Martins Fontes, 2004.

HABERMAS, J. Técnica e ciência como ideologia. In: HABERMAS, J. (org.). Técnica e ciência como "ideologia". Lisboa: Edições 70, 1997. p. 45-92.

HALDANE, J. B. S. Daedalus or Science and the future. Londres: Kegan Paul, Trench, Trubner \& Co., 1923.

HALDANE, J. B. S. Possible worlds. New Brunswick, N.J: Transaction Publishers, 2000.

HALDANE, J. B. S. Everything Has a History. London: Routledge, 2017.

HAMMES, Érico. Transumanismo e Pós-humanismo: uma aproximação ético-teológica. Perspectiva Teológica, Belo Horizonte, v. 50, n. 3, p. 431452, 2018.

HARARI, Yuval Noah. Homo Deus. São Paulo: Companhia das Letras, 2016. HUXLEY, Julian. Knowledge, Morality, and Destiny: I. Psychiatry, v. 14, n. 2, p. 129-140, 1951.

HUXLEY, Julian. Transhumanism. Journal of Humanistic Psychology, v. 8, n. 1, p. 73-76, 1968.

HUXLEY, Julian. Religion without Revelation. New York: Signet, 1969.

HUXLEY, Julian. Ensaios de um humanista. Rio de Janeiro: Editorial Labor do Brasil, 1977. 
JONAS, Hans. Técnica, medicina e ética sobre a prática do princípio responsabilidade. São Paulo: Paulus, 2013.

JONAS, Hans. O princípio responsabilidade: ensaio de uma ética para a civilização tecnológica. Rio de Janeiro: Contraponto, 2006.

KASS, L. R. (ed.). Beyond therapy: biotechnology and the pursuit of happiness. New York: Harper Collins, 2003.

KURZWEIL, Ray. A singularidade está próxima. São Paulo: Iluminuras, 2018.

KURZWEIL, Ray; FERNANDES, Fábio. A era das máquinas espirituais. São Paulo: Aleph, 2007.

KYMLICKA, Will. Filosofia política contemporânea. Uma introdução. São Paulo: Martins Fontes, 2006.

LEWIS, C. S. Collected Letters of C.S. Lewis, Vol. 2: Books, Broadcasts and War 1931-1949. Organizado por Walter Hooper. San Francisco: HarperCollins e-books, 2009.

LEWIS, C. S. A abolição do homem. Rio de Janeiro: Thomas Nelson, 2017.

MACINTYRE, Alasdair. After Virtue: A Study in Moral Theory. 3rd ed. Notre Dame, Indiana. University of Notre Dame Press, 2007.

MARITAIN, Jacques. Man and the State. Chicago: University of Chicago Press, 1966.

MARTINS, Hermínio. Experimentum humanum: civilização tecnológica e condição humana. Belo Horizonte: Fino Traço Ed., 2012.

NOZICK, R. N. Anarchy, State, and Utopia. New York: Basic Books, 1974.

PERSSON, Ingmar; SAVULESCU, Julian. Inadequado para o futuro. Belo Horizonte: Editora UFMG, 2017.

PINHEIRO, Victor Sales; NEIVA, Horácio Lopes Mousinho. Razão Prática, Direito e Bem Comum na Teoria da Lei Natural de John Finnis. Quaestio Iuris, Rio de Janeiro, v. 12, n. 2, p. 240-265, 2019.

POLANYI, Michael. Personal Knowledge: Towards a Post-Critical Philosophy. Chicago: University of Chicago Press, 2009. 
RUBIN, Charles. Daedalus and Icarus Revisited. The New Atlantis, n. 8, p. 73-91, 2005.

RUSE, Michael; WILSON Edward O. The evolution of ethics. New Scientist, n. 108 , p. 50-52, 1985.

RUSSEL, Bertrand. The Scientific Outlook. Routledge Classics. London: Routledge, 2009.

SANDEL, Michael. Contra a perfeição: ética na era da engenharia genética. Rio de Janeiro: Civilização Brasileira, 2013.

SOUZA, Elden Borges; PINHEIRO, Victor Sales. A interdependência entre democracia, bem comum e direitos humanos: contribuições jusnaturalistas. In: PINHEIRO, Victor Sales (org.). A Filosofia do Direito Natural de John Finnis. Vol. 1 Conceitos Fundamentais. Coleção Teoria da Lei natural. Rio de Janeiro: Lumen Juris, 2020. p. 269-298.

SPENCER, H. Social Statics. [S.I]: London, 1892.

TAYLOR, Charles. A ética da autenticidade. São Paulo: É Realizações, 2011.

VALLEJO, Iván Garzón. Bien común, pluralismo y derechos. In: ETCHEVERRY, Juan B. (ed.). Ley, moral y razón. Estudios sobre el pensamiento de John M. Finnis a propósito de la segunda edición de Ley natural y derechos naturales. México: Universidad Nacional Autónoma de México, 2013. p. 141-160.

VILAÇA, M. M.; DIAS, M. C. M. Transhumanismo e o futuro (pós-)humano. Physis, Rio de Janeiro, v. 24, n. 2, p. 341-362, 2014.

VILAÇA, M. M.; PALMA, A. Biological limits, biotechnoscience and transhumanism: a revolution in Public Health? Interface, v. $16, \mathrm{n} .43, \mathrm{p}$. 1025-1038, out./dez. 2012.

WOLSTENHOLME, Gordon. Man and his Future. London: Ciba Foundation, 1963. 